\title{
Equilibrium modelling of Cr (VI) biosorption by olive stone
}

\author{
M. Calero, F. Hernáinz, G. Blázquez, M. A. Martín-Lara \\ \& G. Tenorio \\ Department of Chemical Engineering, Faculty of Science, \\ University of Granada, Spain
}

\begin{abstract}
In this study, $\mathrm{Cr}$ (VI) biosorption isotherms were investigated depending on temperature by employing batch biosorption technique and using olive stone as sorbent. To analyse the effect of the temperature in the equilibrium of the biosorption process, experiments were carried out by varying the concentration from 10 to $220 \mathrm{mg} / \mathrm{L}$, at three temperatures: $25^{\circ} \mathrm{C}, 60^{\circ} \mathrm{C}$ and $80^{\circ} \mathrm{C}$.

The increase in temperature favoured biosorption and reduction processes, thus, for a specific initial $\mathrm{Cr}$ (VI) concentration, as temperature increases, the final $\mathrm{Cr}$ (VI) concentration that remains in the solution decreases, and the $\mathrm{Cr}$ (III) concentration increases.

The experimental data were adjusted to Langmuir, Freundlich and RedlichPeterson models, the Langmuir model being the one that best reproduced the experimental results for all the chosen temperatures. From the results obtained it concluded that the maximum sorption capacity increases as the temperature increases, from a value of $1.728 \mathrm{mg} / \mathrm{g}$ at $25^{\circ} \mathrm{C}$ to $4.824 \mathrm{mg} / \mathrm{g}$ at $80^{\circ} \mathrm{C}$. Similarly, the affinity parameter also increases with temperature, from $0.112 \mathrm{~L} / \mathrm{mg}\left(25^{\circ} \mathrm{C}\right)$ to $0.472 \mathrm{~L} / \mathrm{mg}\left(80^{\circ} \mathrm{C}\right)$.

Finally, using the values obtained for the constant $\mathrm{b}$ of the Langmuir model, the changes in enthalpy, $\mathrm{H}$, free energy, $\mathrm{G}$, and entropy, $\mathrm{S}$, were determined and it obtained that for $\mathrm{Cr}$ (VI) the process was endothermic, since the enthalpy had a positive value, and the negative free energy values, $\Delta \mathrm{G}$, showed the spontaneous nature of the process and that it was favoured by the increase in temperature.
\end{abstract}

Keywords: biosorption, heavy metals, equilibrium, olive stone, chromium. 


\section{Introduction}

$\mathrm{Cr}$ (VI) is one of the most toxic metals due to its mutagenic and carcinogenic properties according to the US EPA. Cr (VI) is mainly introduced into natural waters from a variety of industrial wastewaters including those from electroplating, leather tanning, textile dyeing and metal finishing industries [1].

The removal of heavy metal contaminated wastewater is generally accomplished by conventional methods such as chemical precipitation, membrane separations or resin ion exchange but these methods have limitations and often are not economically viable, produces large quantity of toxic waste sludge or the metal removal is incomplete especially for the removal of heavy metals at low concentrations.

Biosorption has been proposed as an alternative method because of its ecofriendly nature, excellent performance and low cost [2].

The objective of this study was to investigate the possible use of olive stone as an alternative biosorbent material for removal $\mathrm{Cr}$ (VI) ions from aqueous solutions. The paper reports the results for equilibrium studies at three temperatures: $25^{\circ} \mathrm{C}, 60^{\circ} \mathrm{C}$ and $80^{\circ} \mathrm{C}$. Equilibrium isotherm models were applied to establish the biosorption capacity. Thermodynamic parameters were also evaluated from the biosorption measurements.

\section{Materials and methods}

\subsection{Biosorbent: olive stone}

Olive stones were supplied by the olive cake oil extraction plant "Orujera Ubetense, Sociedad Cooperativa Andaluza', located in Ubeda, province of Jaen, Spain.

The stones were obtained from the separation process of the olive cake with an industrial pitting machine, with a $4 \mathrm{~mm}$ sieve-separator, which is the standard size used in this industrial process. Then, the olive stones were milled in laboratory from an initial size ranging of $4 \mathrm{~mm}$ to a fraction lower than $1 \mathrm{~mm}$ and it is the solid used for the entire test.

\subsection{Equilibrium tests}

The experiments were performed by mixing $0.5 \mathrm{~g}$ of olive stone in $50 \mathrm{~mL}$ of the synthetic $\mathrm{Cr}$ (VI) solutions. Solutions of $\mathrm{Cr}$ (VI) were prepared in distilled water using the following metal salt $\mathrm{Cr}\left(\mathrm{NO}_{3}\right)_{3} \cdot 9 \mathrm{H}_{2} \mathrm{O}$.

Equilibrium isotherm studies were conducted at 25,40 and $60^{\circ} \mathrm{C}$ with constant amount of olive stone $(10 \mathrm{~g} / \mathrm{L})$ at the constant $\mathrm{pH} 2$ during 300 minutes and for initial $\mathrm{Cr}$ (VI) concentration between 10-220 mg/L.

The solutions were taken and placed in a $100 \mathrm{~mL}$ jacketed reactor that is connected to a thermostat-controlled bath, $\mathrm{pH}$ of the solution was adjusted with $0.1 \mathrm{M} \mathrm{HCl}$ or $0.1 \mathrm{M} \mathrm{NaOH}$ solutions and temperature set at the desired value.

Once the operation time had elapsed, the liquid phase was taken out of the reactor, centrifuged for $10 \mathrm{~min}$, then the supernatant solution was filtered and 
analysed for determined metal concentrations by a spectrophotometer (Termo, Genesys $6 \mathrm{UV} / \mathrm{VIS}$ ) at $540 \mathrm{~nm}$ after complex at ion with 1,5-diphenyl carbazide [3]. The total $\mathrm{Cr}$ concentration in the aqueous samples was determined using a flame atomic absorption (AA) spectrophotometer (Perkin Elmer Model 3100) and $\mathrm{Cr}$ (III) concentration by difference.

The amount of metal ion absorbed at equilibrium per unit mass of biosorbent was determined according to the following equation:

$$
\mathrm{q}_{\mathrm{e}}=\frac{\left(\mathrm{C}_{\mathrm{i}}-\mathrm{C}_{\mathrm{e}}\right)}{\mathrm{m}} \cdot \mathrm{V}
$$

where $\mathrm{q}_{\mathrm{e}}$ is the metal uptake at equilibrium (mg metal/g biosorbent), $\mathrm{V}$ the liquid volume (L), $\mathrm{C}_{\mathrm{i}}$ the initial concentration of $\mathrm{Cr}(\mathrm{VI})$ in the solution $(\mathrm{mg} / \mathrm{L}), \mathrm{C}_{\mathrm{e}}$ the equilibrium concentration of metal in the solution $(\mathrm{mg} / \mathrm{L})$, and $\mathrm{m}$ the amount of the biosorbent sample on a dry basis $(\mathrm{g})$.

Each experiment was carried out at least twice to check reproducibility of the results and biomass-free blanks were used as control.

\section{Results and discussion}

\subsection{Equilibrium models}

The biosorption equilibrium is described by mathematical models (sorption isotherms), which relate the retained amount of the sorbate and what remains in the solution once the equilibrium is reached, at a constant temperature [4].

Although numerous models appear in the literature for the study of equilibrium in biosorption systems [5], the most used are the Langmuir model and the Freundlich model. In this study, these two models have been used, as well as the Redlich-Peterson model, which incorporates the characteristics of the first two to describe the biosorption equilibrium of chromium using olive stone as a solid sorbent.

The Langmuir isotherm can be represented by the following expression [6],

$$
\mathrm{q}_{\mathrm{e}}=\frac{\mathrm{bq}_{\mathrm{m}} \mathrm{C}_{\mathrm{e}}}{1+\mathrm{bC}_{\mathrm{e}}}
$$

where $\mathrm{q}_{\mathrm{e}}$ is the sorption capacity at equilibrium $(\mathrm{mg} / \mathrm{g}), \mathrm{C}_{\mathrm{e}}$ is the final equilibrium concentration of metal ion at liquid phase $(\mathrm{mg} / \mathrm{L}), \mathrm{q}_{\mathrm{m}}$ and $\mathrm{b}$ are the Langmuir constants, related to the maximum sorption capacity for a complete monolayer $(\mathrm{mg} / \mathrm{g})$ and to the affinity between the sorbent and sorbate $(\mathrm{L} / \mathrm{mg})$, respectively.

In 1906, Freundlich [7] studied the sorption of a material in coal of animal origin and found a potential relationship between the absorbed solute and the equilibrium concentration which can be expressed by means of the following equation

$$
\mathrm{q}_{\mathrm{e}}=\mathrm{K}_{\mathrm{F}} \mathrm{C}_{\mathrm{e}}^{1 / \mathrm{n}}
$$


where $\mathrm{q}_{\mathrm{e}}$ and $\mathrm{C}_{\mathrm{e}}$ have the same meaning as in the Langmuir isotherm, $\mathrm{K}_{\mathrm{F}}$ is the equilibrium constant $\left((\mathrm{mg} / \mathrm{g}) \cdot(\mathrm{L} / \mathrm{mg})^{1 / \mathrm{n}}\right)$ and $\mathrm{n}$ is a constant related to the affinity between the sorbent and the sorbate.

The Redlich-Peterson isotherm contains three parameters and incorporates the characteristics of the Langmuir and Freundlich isotherms [8]. This isotherm has a linear relationship with the concentration in the numerator and an exponential function in the denominator, and can be expressed as follows [4]:

$$
\mathrm{q}_{\mathrm{e}}=\frac{\mathrm{AC}_{\mathrm{e}}}{1+\mathrm{BC}_{\mathrm{e}}^{\mathrm{g}}}
$$

where $\mathrm{A}$ and $\mathrm{B}$ are two constants $\left(\mathrm{L} / \mathrm{g}\right.$ and $(\mathrm{L} / \mathrm{mg})^{\mathrm{g}}$, respectively), $\mathrm{g}$ is a parameter whose value is limited between 0 and 1 , thus when $g=1$ it converts to the Langmuir isotherm form and when $\mathrm{g}=0$ it converts to the Henry law.

\subsection{Modelling}

In literature it has been verified that $\mathrm{Cr}$ (VI) can be easily reduced to $\mathrm{Cr}$ (III) in the presence of particular solid sorbents and in acid media. Therefore, it can be stated that the mechanism for chromium retention would really imply two simultaneous processes [9-11].

- The reduction of $\mathrm{Cr}$ (VI) to $\mathrm{Cr}$ (III) in presence of the biosorbent and in acid media.

- The retention of the initially present $\mathrm{Cr}$ (VI) by the biosorbent, as well as of the $\mathrm{Cr}$ (III) formed during the reduction process.

To analyse the effect of the initial Cr (VI) concentration in the process of biosorption, experiments were carried out by varying the concentration from 10 to $220 \mathrm{mg} / \mathrm{L}$, at three temperatures: $25^{\circ} \mathrm{C}, 60^{\circ} \mathrm{C}$ and $80^{\circ} \mathrm{C}$. A contact time of 300 min and a $\mathrm{pH}$ equal to 2 were chosen considering previous results. Figure 1 illustrates the final concentration of $\mathrm{Cr}$ (VI) and $\mathrm{Cr}$ (III) in solution as a function of the initial $\mathrm{Cr}$ (VI) concentration and temperature, with the objective to observe more clearly the effect of the reduction to $\mathrm{Cr}$ (III) on the $\mathrm{Cr}$ (VI) retention by olive stone.

It can be observed that the temperature favours both the biosorption and the reduction processes, thus, for a specific initial $\mathrm{Cr}$ (VI) concentration, as temperature increases, the final $\mathrm{Cr}$ (VI) concentration that remains in the solution decreases, and the $\mathrm{Cr}$ (III) concentration also increases, this being more important when the temperature increases from $60^{\circ} \mathrm{C}$ to $80^{\circ} \mathrm{C}$. Also, at $80^{\circ} \mathrm{C}$ it can be observed that an increase in the initial $\mathrm{Cr}$ (VI) concentration also causes an increase in its reduction to $\mathrm{Cr}$ (III), an effect which is not observed at lower temperatures, although it must be taken into consideration that the $\mathrm{Cr}$ (III) concentrations in solution are very low (especially at $25^{\circ} \mathrm{C}$ ) and in some cases could be within the error range inherent to the applied analytical systems.

These results have been adjusted to the three models considered (Langmuir, Freundlich and Redlich-Peterson) and the results obtained for the parameters of each of these models are reported in Tables 1 and 2 for total $\mathrm{Cr}$ and $\mathrm{Cr}$ (VI), respectively. 


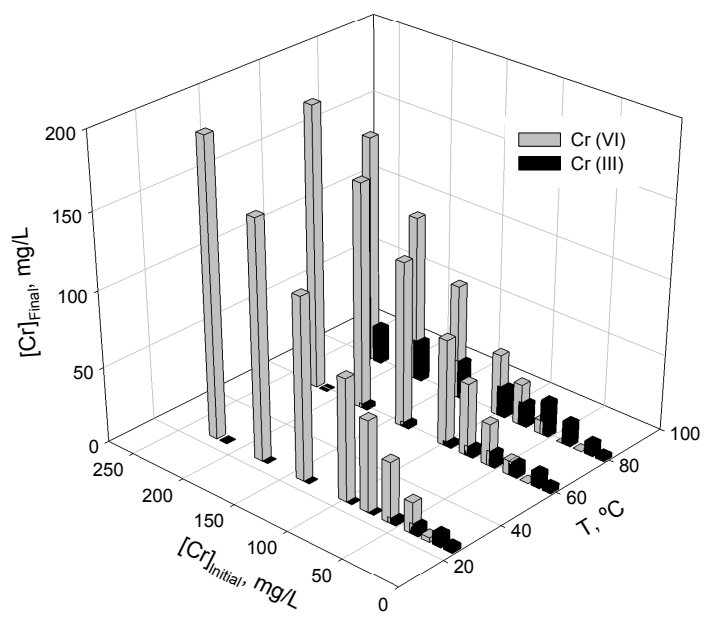

Figure 1: $\quad$ Final concentration of $\mathrm{Cr}$ (VI) and $\mathrm{Cr}$ (III) in solution as a function of the initial $\mathrm{Cr}(\mathrm{VI})$ concentration and temperature.

Table 1: Parameters of Langmuir, Freundlich and Redlich-Peterson isotherms for total chromium sorption onto olive stone at various temperatures.

\begin{tabular}{|c|c|c|c|c|c|c|c|c|c|c|c|}
\cline { 2 - 12 } \multicolumn{1}{c|}{} & \multicolumn{10}{c|}{ Total Cr } \\
\hline \multirow{2}{*}{$\mathbf{T}^{\circ}{ }^{\circ} \mathbf{C}$} & \multicolumn{3}{|c|}{ Langmuir } & \multicolumn{3}{c|}{ Freundlich } & \multicolumn{5}{c|}{ Redlich-Peterson } \\
\cline { 2 - 13 } & $\mathrm{q}_{\mathrm{m}}$ & $\mathrm{b}$ & $\mathrm{r}^{2}$ & $\mathrm{~K}_{\mathrm{F}}$ & $\mathrm{n}$ & $\mathrm{r}^{2}$ & $\mathrm{~A}$ & & $\mathrm{~g}$ & $\mathrm{r}^{2}$ & $\mathrm{~s}^{2}$ \\
\hline 25 & 2.168 & 0.0288 & 0.98 & 0.182 & 2.16 & 0.92 & 0.073 & 0.039 & 0.98 & 0.98 & 0.054 \\
\hline 60 & 2.446 & 0.0469 & 0.99 & 0.293 & 2.39 & 0.90 & 0.123 & 0.057 & 0.97 & 0.99 & 0.145 \\
\hline 80 & 3.666 & 0.0480 & 0.99 & 0.370 & 2.15 & 0.91 & 0.189 & 0.060 & 0.97 & 0.99 & 0.186 \\
\hline
\end{tabular}

It can be observed that, for both the total $\mathrm{Cr}$ and $\mathrm{Cr}$ (VI), the Langmuir model is the one that best reproduces the experimental results for all the chosen temperatures, which is also confirmed by the adjustment with the RedlichPeterson model where the value g obtained clearly tends to one and, therefore, taking into consideration the limit this parameter represents, to the Langmuir isotherm.

On the other hand, from the results obtained for $\mathrm{Cr}$ (VI) it has been concluded that the maximum sorption capacity, $\mathrm{q}_{\mathrm{m}}$, increases as the temperature increases, from a value of $1.728 \mathrm{mg} / \mathrm{g}$ at $25^{\circ} \mathrm{C}$ to $4.824 \mathrm{mg} / \mathrm{g}$ at $80^{\circ} \mathrm{C}$. Similarly, the parameter $b$ also increases with temperature, from $0.112 \mathrm{~L} / \mathrm{mg}$ to $0.472 \mathrm{~L} / \mathrm{mg}$ when the temperature increases from $25^{\circ} \mathrm{C}$ to $80^{\circ} \mathrm{C}$.

These results suggest, as has been previously indicated, that an increase in temperature favours the $\mathrm{Cr}$ (VI) retention by olive stone, although it should be taken into consideration that a greater reduction from $\mathrm{Cr}$ (VI) to $\mathrm{Cr}$ (III) also 
takes place, therefore, the effect of temperature in the total $\mathrm{Cr}$ is less important since, in this case, $\mathrm{q}_{\mathrm{m}}$ increases from $2.168 \mathrm{mg} / \mathrm{g}$ at $25^{\circ} \mathrm{C}$ to $3.666 \mathrm{mg} / \mathrm{g}$ at $80^{\circ} \mathrm{C}$.

There are few studies in literature that simultaneously analyse the effect of $\mathrm{Cr}$ (VI) biosorption and its reduction to $\mathrm{Cr}$ (III) since the majority of researchers report a maximum sorption capacity value without taking into consideration that part of the $\mathrm{Cr}$ (VI) removed by the biosorption really remains in the solution as $\mathrm{Cr}$ (III) [12-14].

Table 2: Parameters of Langmuir, Freundlich and Redlich-Peterson isotherms for $\mathrm{Cr}$ (VI) sorption onto olive stone at various temperatures.

\begin{tabular}{|c|c|c|c|c|c|c|c|c|c|c|c|}
\hline \multirow{3}{*}{$\mathrm{T},{ }^{\circ} \mathrm{C}$} & \multicolumn{11}{|c|}{$\mathrm{Cr}$ (VI) } \\
\hline & \multicolumn{3}{|l|}{$\mathbf{L}$} & \multicolumn{3}{|c|}{ Freundlich } & \multicolumn{5}{|c|}{ Redlich-Peterson } \\
\hline & $\mathrm{q}_{\mathrm{m}}$ & b & $r^{2}$ & $\mathrm{~K}_{\mathrm{F}}$ & $\mathrm{n}$ & $\mathrm{r}^{2}$ & A & B & $\mathrm{g}$ & $r^{2}$ & $s^{2}$ \\
\hline 25 & 1.728 & 0.112 & 0.98 & 0.735 & 6.20 & 0.70 & 0.302 & 0.184 & 0.99 & 0.99 & 0.532 \\
\hline 60 & 2.348 & 0.489 & 0.99 & 1.817 & 11.83 & 0.90 & 1.116 & 0.493 & 0.99 & 0.99 & 0.690 \\
\hline 80 & 4.824 & 0.472 & 0.99 & 2.612 & 7.54 & 0.91 & 1.940 & 0.560 & 0.92 & 0.97 & 0.807 \\
\hline
\end{tabular}

With the objective to compare experimental data and models in Figure 2 was represented the chromium retention capacity values, $\mathrm{q}_{\mathrm{e}}$, versus the chromium equilibrium concentration, $\mathrm{C}_{\mathrm{e}}$, in the liquid phase, for total $\mathrm{Cr}$ and for $\mathrm{Cr}$ (VI), respectively.

The essential characteristics of the Langmuir isotherm can be expressed by a dimensionless constant (separation factor or equilibrium parameter) $\mathrm{R}_{\mathrm{L}}$, defined by the following expression

$$
\mathrm{R}_{\mathrm{L}}=\frac{1}{1+\mathrm{b} \mathrm{C}_{\mathrm{i}}}
$$

where $\mathrm{b}$ is the Langmuir constant and $\mathrm{C}_{\mathrm{i}}$ is the initial $\mathrm{Cr}$ (VI) concentration, $\mathrm{mg} / \mathrm{L}$.

The $\mathrm{R}_{\mathrm{L}}$ constant indicates the type of isotherm, thus, for values between 0 and 1 sorption is favourable [15-17]. Figure 3 represents the $R_{L}$ values with regard to the initial chromium concentration and for the three temperatures used. It can be observed that these values are between 0 and 1 for all the operational conditions used, which indicates that the retention of $\mathrm{Cr}$ (VI) using olive stone is a favourable process.

\subsection{Thermodynamic parameters}

In order to describe thermodynamic behaviour of the biosorption of $\mathrm{Cr}$ (VI) ions onto olive stone, thermodynamic parameters including the change in free energy $(\Delta \mathrm{G})$, enthalpy $(\Delta \mathrm{H})$ and entropy $(\Delta \mathrm{S})$ were calculated in accordance with the following expressions $[18,19]$.

$$
\Delta \mathrm{G}=-\mathrm{R} \mathrm{T} \ln \mathrm{b}
$$




$$
\ln \mathrm{b}=\frac{\Delta \mathrm{S}}{\mathrm{R}}-\frac{\Delta \mathrm{H}}{\mathrm{R} \mathrm{T}}
$$

where $\mathrm{R}$ is the universal gas constant $(8.314 \mathrm{~J} / \mathrm{mol} \mathrm{K})$, $\mathrm{T}$ is temperature $(\mathrm{K})$ and $\mathrm{b}$ is the Langmuir constant $(\mathrm{L} / \mathrm{mg})$.

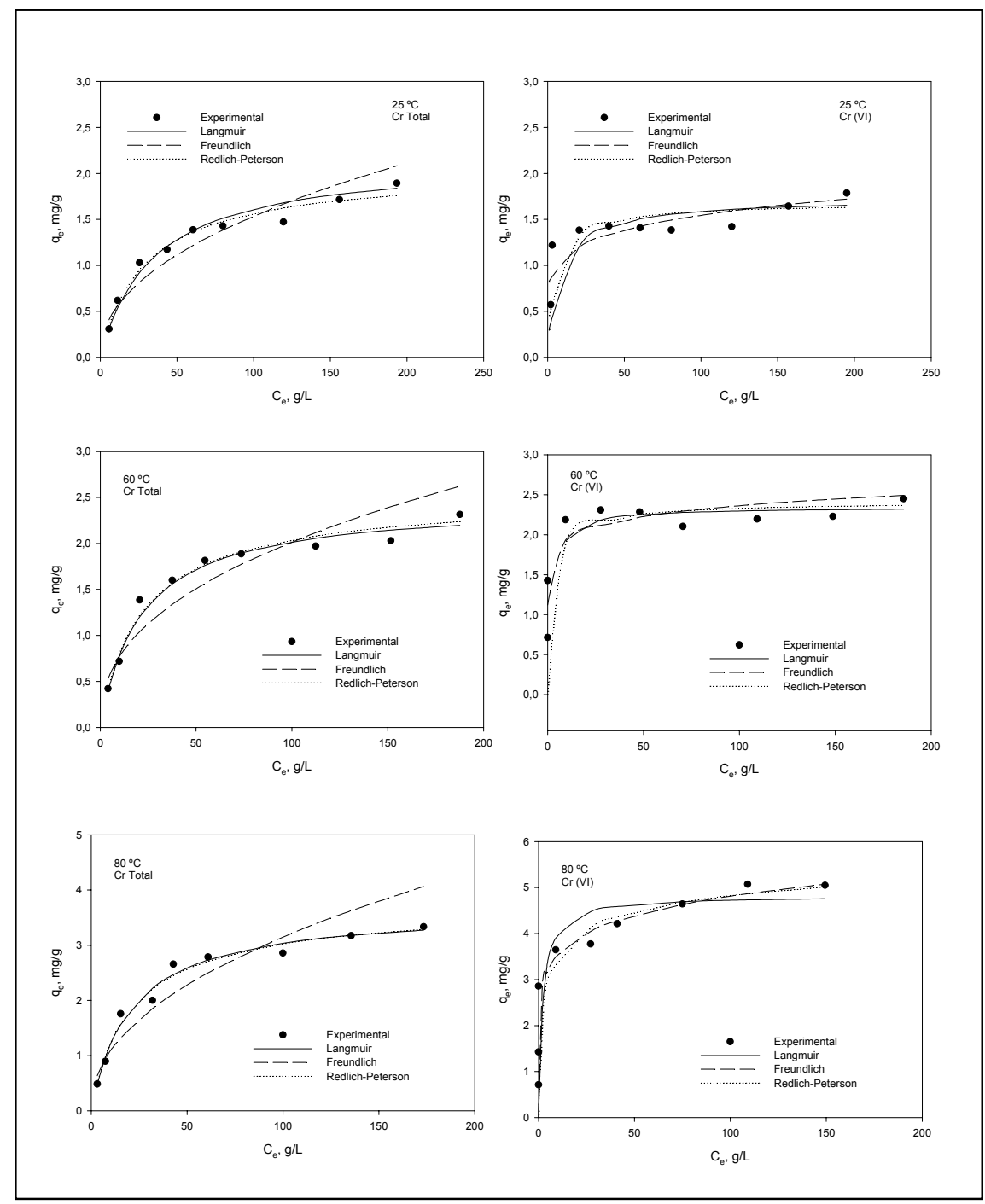

Figure 2: $\quad$ Langmuir, Freundlich and Redlich-Peterson isotherms for total $\mathrm{Cr}$ and $\mathrm{Cr}$ (VI) sorption at various temperatures (solution $\mathrm{pH} \mathrm{2}$; contact time $300 \mathrm{~min}$; biosorbent concentration $10 \mathrm{~g} / \mathrm{L}$ ). 


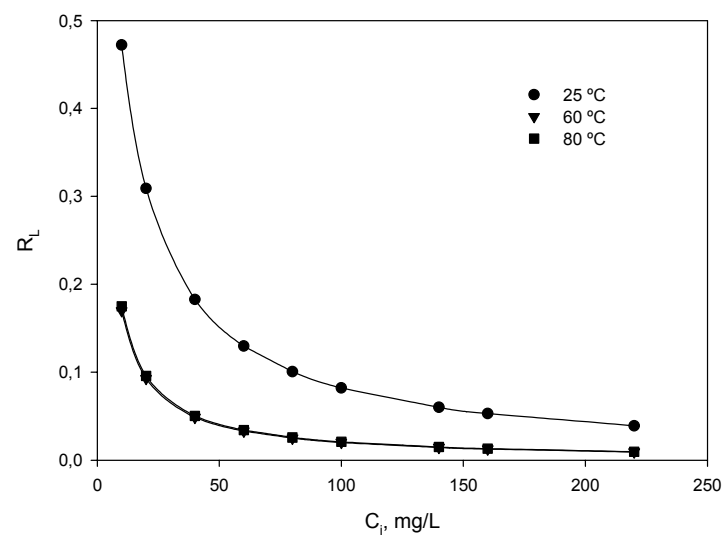

Figure 3: Representation of $\mathrm{R}_{\mathrm{L}}$ parameter versus initial $\mathrm{Cr}$ (VI) concentration at various temperatures.

Table 3: Thermodynamic parameters for $\mathrm{Cr}$ (VI) sorption onto olive stone at various temperatures.

\begin{tabular}{|c|c|c|c|}
\hline T. ${ }^{\circ} \mathrm{C}$ & $\Delta \mathrm{G}, \mathrm{kJ} / \mathrm{mol}$ & $\Delta \mathrm{H}, \mathrm{kJ} / \mathrm{mol}$ & $\Delta \mathrm{S}, \mathrm{J} / \mathrm{mol}$ \\
\hline 25 & -4.359 & \multirow{3}{*}{24.67} & \multirow{3}{*}{98.29} \\
\hline 60 & -8.953 & & \\
\hline 80 & -9.388 & & \\
\hline
\end{tabular}

Table 3 reported the results found for $\mathrm{Cr}$ (VI). For $\mathrm{Cr}$ (VI) the process is endothermic, since the enthalpy has a positive value, and the negative free energy values, $\Delta \mathrm{G}$, shows the spontaneous nature of the process and that it favoured by the increase in temperature and $\Delta \mathrm{S}$ showed the irreversibility of $\mathrm{Cr}$ (VI) biosorption. These results are similar to those found by other researchers for the elimination of heavy metals using solid sorbents of different natures. In this way, Das et al. [20] found a $\Delta \mathrm{H}$ value of $9.39 \mathrm{~kJ} / \mathrm{mol}$ and $\Delta \mathrm{G}$ values that vary from $-23.50 \mathrm{~kJ} / \mathrm{mol}$ to $-27.02 \mathrm{~kJ} / \mathrm{mol}$ for a range of temperatures from $30^{\circ} \mathrm{C}$ to $60^{\circ} \mathrm{C}$, for the $\mathrm{Cr}$ (VI) biosorption by active carbon extracted from cow dung; Tewari et al. [21] in their Cr (VI) biosorption study with Mucor hiemalis, indicated a $\Delta \mathrm{H}$ value of $19.6 \mathrm{~kJ} / \mathrm{mol}$ and a $\Delta \mathrm{G}$ change from $-18.4 \mathrm{~kJ} / \mathrm{mol}$ to $21.3 \mathrm{~kJ} / \mathrm{mol}$ as temperature increases from $27^{\circ} \mathrm{C}$ to $50^{\circ} \mathrm{C}$ and Hamadi et al. [12] found that $\Delta \mathrm{G}$ changes from $-12.33 \mathrm{~kJ} / \mathrm{mol}$ to $-13.86 \mathrm{~kJ} / \mathrm{mol}$ in a temperature range of $22^{\circ} \mathrm{C}$ to $38^{\circ} \mathrm{C}$, during $\mathrm{Cr}$ (VI) biosorption by active carbon obtained from rubber.

\section{Conclusions}

Equilibrium biosorption performance of olive stone was investigated for the removal of $\mathrm{Cr}$ (VI) from single aqueous solutions. The Langmuir, Freundlich and 
Redlich-Peterson models were used for the mathematical description of the biosorption equilibrium. The equilibrium experimental data at various temperatures fitted well to the Langmuir isotherm. The apparent thermodynamic parameters suggest that the process is endothermic, spontaneous and irreversible. But the most important conclusion of this work is the verification of that the mechanism for chromium retention really imply two simultaneous processes: the reduction of $\mathrm{Cr}$ (VI) to $\mathrm{Cr}$ (III) and the retention of the initially present $\mathrm{Cr}$ (VI) by the biosorbent, as well as of the $\mathrm{Cr}$ (III) formed during the reduction process.

\section{References}

[1] Wang, X.S., Li, Z.Z. \& Sun, C., Removal of Cr (VI) from aqueous solutions by low-cost biosorbents: Marine macroalgae and agricultural byproducts. Journal of Hazardous Materials, 2007. doi:10.1016/j. jhazmat.2007.09.079

[2] Ertugay, N. \& Bayhan, Y.K., Biosorption of Cr (VI) from aqueous solutions by biomass of Agaricus bisporus. Journal of Hazardous Materials, 2007. doi:10.1016/j.jhazmat.2007.10.070

[3] Greenberg, A.E., Trussell, R.R. \& Clescery, L.S., Standard methods for the examination of water and waste water. American Public Health Association (APHA), 16th ed. AWWA, WPCF, Washington DC. pp. 201-204, 1985.

[4] Ho, Y.S., Huang, C.T. \& Huang, H.W., Equilibrium sorption isotherm for metals ions on tree fern. Process Biochemistry, 37(12), pp. 1421-1430, 2002.

[5] Volesky, B., Biosorption process simulation tools. Hydrometallurgy, 71(12), pp. 179-190, 2003.

[6] Langmuir, I., The adsorption of gases on plane surfaces of glass, mica and platinum. Journal of American Chemistry Society, 40(9), pp. 1361-1403, 1918.

[7] Freundlich, H., Colloid and capillary chemistry, Methuen, London, UK, 1926.

[8] Redlich, O. \& Peterson, D.L., A useful adsorption isotherm. Journal of Physical Chemistry, 63(6), pp. 1024-1024, 1959.

[9] Selomulya, C., Meeyoo, V. \& Amal, R., Mechanisms of Cr (VI) removal from water by various types of activated carbons. Journal of Chemical Technology and Biotechnology, 74(2), pp. 111-122, 1999.

[10] Park, D., Yun, Y.S. \& Park, J.M., Studies on hexavalent chromium biosorption by chemically-treated biomass of Ecklonia sp. Chemosphere, 60(10), pp. 1356-1364, 2005.

[11] Romero-González, J., Cano-Rodríguez, I., Walton, J.C., Peralta-Videa, J.R., Rodríguez, E. \& Gardea-Torresdey, J.L., A model to describe the adsorption and reduction of $\mathrm{Cr}$ (VI) from an aqueous solution by Agave lechuguilla biomass. Revista Mexicana de Ingeniería Química, 4(3), pp. 261-272, 2005.

[12] Hamadi, N.K., Chen, X.D., Farid, M.M. \& Lu, M.G.Q., Adsorption kinetics for the removal of chromium (VI) from aqueous solution by adsorbents 
derived from used tyres and sawdust. Chemical Engineering Journal, 84(2), pp. 95-105, 2001.

[13] Babel, S. \& Kurniawan, T.A., Cr (VI) removal from synthetic wastewater using coconut shell charcoal and commercial activated carbon modified with oxidizing agents and/or chitosan. Chemosphere, 54(7), pp. 951-967, 2004.

[14] Bajpai, J., Shrivastava, R. \& Bajpai, A.K., Dynamic and equilibrium studies on adsorption of $\mathrm{Cr}$ (VI) ions onto binary bio-polymeric beads of cross linked alginate and gelatine. Colloids and Surfaces A: Physicochemical and Engineering Aspects, 236(1-3), pp. 81-90, 2004.

[15] Mckay, G., Blair, H.S. \& Gardner, J.K., Adsorption of dyes on chitin 1. Equilibrium studies. Journal of Applied Polymer Science, 27(8), pp. 3043 3057, 1982.

[16] Aravindhan, R., Madhan, B., Rao, J.R. \& Nair, B.U., Recovery and reuse of chromium from tannery wastewaters using Turbinaria ornata seaweed. Journal of Chemical Technology and Biotechnology, 79(11), pp. 12511258, 2004.

[17] Namasivayam, C. \& Höll, W.H., Chromium(III) removal in tannery waste waters using chinese reed (Miscanthus sinensis), a fast growing plant. Holz Als Roh-Und Werkstoff, 62(1), pp. 74-80, 2004.

[18] Sawalha, M.F., Peralta-Videa, J.R., Romero-González, J. \& GardeaTorresdey, J.L., Biosorption of Cd (II), Cr (III) and Cr (VI) by saltbush (Atriplex canescens) biomasa: Thermodynamic and isotherm studies. Journal of Colloid Interface and Science, 300(1), pp. 100-104, 2006.

[19] Aravindhan, R., Rao, J.R., Nair, B.U., Removal of basic yellow dye from aqueous solution by sorption on green alga Caulerpa scalpelliformi. Journal of Hazardous Materials, 142(1-2), pp. 68-76, 2007.

[20] Das, D.D., Mahapatra, R., Pradhan, J., Das, S.N. \& Thakur, R.S., Removal of $\mathrm{Cr}$ (VI) from aqueous solution using activated cow dung carbon. Journal of Colloid and Interface Science, 232(2), pp. 235-240, 2000.

[21] Tewari, N., Vasuevan, P. \& Guha, B.K., Study on biosorption of Cr (VI). Biochemical Engineering Journal, 23(2), pp. 185-192, 2005. 